\title{
Concept for Eritrea's Sustainable Economic Development Red Sea, the Natural Dam of Eritrea
}

\author{
Hossana Solomon
}

\begin{abstract}
The Danakil Depression is located in Eritrea, a few kilometers inland from the Red Sea coast and sinks 120 meters below sea level. This concept paper attempts to explore Eritrea's ability to develop a hydroelectric and potable water generation capacity from the Red Sea. Unlike many countries with access to seas and oceans, Eritrea is endowed with a natural hydro dam because of its geographical location and topography. The Red Sea can be used as a resource for the production of energy as hydro dam and potable water source through desalination. The availability of cheap, clean and environmentally safe energy and water sources will enable the country to eliminate poverty and stop environmental degradation, thus contributing to reduce or minimize the global warming problem.
\end{abstract}

Index Terms-Danakil-depression, economics, Eritrea, hydroelectric-power, red sea

\section{INTRODUCTION}

Eritrea is a young nation, only 20 years old since it achieved its independence in 1993. It is located in the Horn of Africa, bordered in the north and west by Sudan, in the south by Ethiopia and Djibouti, and in the east by the Red Sea Fig. 1. It has an estimated population of about 5.9 million and a total land area of some 12.2 million hectares. Its annual population growth is estimated at 2.9 percent [1]. Eritrea is a poor country and faces economical and environmental challenges. Both challenges lead to wide spread poverty for the population. The economic challenges relate to resource constraints to meet the national demand for commercial energy production and inadequate water resources needed for agriculture, mining manufacturing, or service industries [2]. The environmental challenges stem from the global warming phenomenon, due to the expansion of the Sahara desert which causes frequent drought across the Sub-Saharan Sahel region. The economic challenge also contributes to wide spread deforestation and overgrazing for subsistence, exposing the barren land to water and wind erosions [3].

Subsistence crop production and cattle keeping are the two most important economic activities in Eritrea [4]. However, these traditional production methods and livestock populations used in much of the country contribute heavily to land degradation and soil erosion. Desertification due to overgrazing and soil erosion is common in many parts of the country. Energy requirements also put a lot of pressure on the

Manuscript received February 4, 2013; revised April 9, 2013. This work was supported in part by the University of the Virgin Islands Faculty Professional Development Fund. The Author also acknowledges the support received from the Ministry of Agriculture Government of Eritrea for travel and lodging to visit the Red Sea Coast and the Danakil Depression.

Hossana Solomon is with the University of the Virgin Islands, St. Thomas, USVI 00802 USA. (e-mail:hsolomo@live.uvi.edu). environment as large quantities of wood and trees are needed for energy generation in Eritrea Fig. 2.

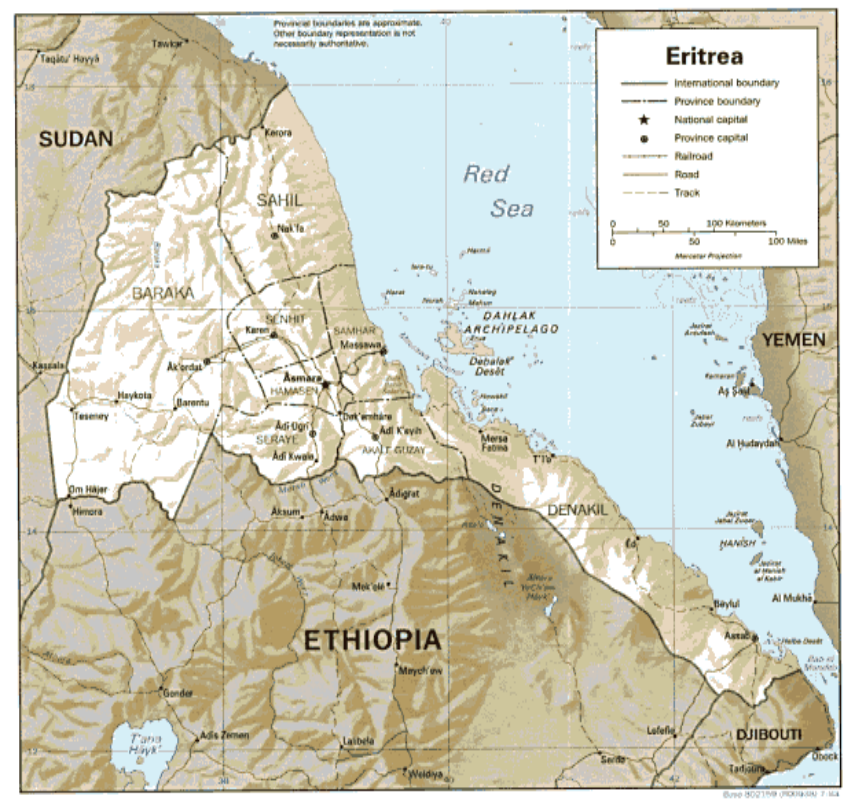

Fig. 1. Map of Eritrea source Google maps

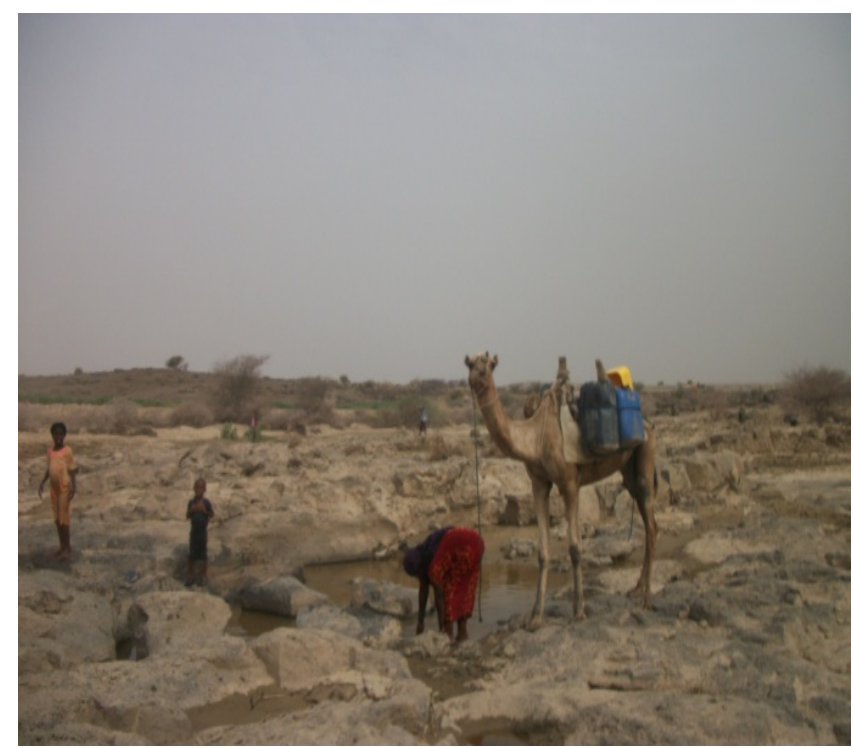

Fig. 2. Eritrean children and women fetching for water and firewood in the Danakil Depression area. Source H. Solomon

With a per capita income of only about 700 USD, Eritrea is considered one of the world's poorest countries, ranks $219^{\text {th }}$. in 2010 and 2011 [4]. The country's underdevelopment partly can be attributed to the 500 years chain of colonization. Its location of bordering of $1000 \mathrm{~km}$ along the western Red Sea coast had attracted several foreign military powers for almost five centuries. The Ottoman Empire, followed by Egyptian and Italian colonization, has left their impact in the region. 
The Italians occupied Eritrea from the end of the $19^{\text {th }}$ Century to the end of World War II, after which Italian colonization was replaced by the British Empire. In 1951, due to U.S. strategic interest in the region, the U.N. federated Eritrea with the Ethiopian Empire and the country became the battle ground for Eritrean struggle for independence. In 1991 after thirty years of bloody war that practically destroyed all economic activities and infrastructure of the country, Eritrea won the war and declared its political independence and since it is struggling to achieve its economic independence facing several challenges [5].

Eritreans have one of the world's lowest energy production and consumption rates. According to World Bank data, Electrical production in Eritrea is about 300 Mega Watt in 2010 which is one of the lowest in Africa and the per capita gross electrical power consumption in Eritrea for the same period reported about $50 \mathrm{~kW}$-hr/year is also the lowest in Africa. Commercial energy consumption in other developing countries is much higher [6].

As a young independent country Eritrea is not endowed with natural perennial rivers that can be used as sources of hydro electricity generation, as the case for many nations, nor does it have hydrocarbon resources like coal, oil or natural gas that can be exploited to generate cheap electrical power. Even though there were and may still be exploration of hydrocarbon resources in Eritrea, they have not yet materialized [7]. Therefore energy and water are not sufficiently available in the country and because of these facts Eritrea's economic development drive can be hampered both in the short and long run.

\section{LITERATURE REVIEW}

There are several locations around the world where land sinks below sea level. There are three particular sites in Africa and one in the Middle East that allow for the possibility of high capacity hydroelectric generation capacities operating between the sea and a depression that is below sea level: 1) The Danakil Depression in Eritrea, Ethiopia, 2) the Qattara depression in Egypt, 3) Lake Assal and the surrounding Afar depression area in Djibouti, and 4) the Dead Sea Depression between Jordan and Israel border.

The idea of using the sea as a source of hydroelectric power is not new. There are examples from other depression localities close to the Red Sea. The one which is currently actively pursued is called The Jordanian-Israeli "peace canal," or Red-Dead Canal Project, which aims to save the Dead Sea from drying up.

The Dead Sea lies between the Jordanian-Israeli border and is vital for tourism and natural resources. The would-be canal would extend $180 \mathrm{~km}$ (112 miles) from the Gulf of Aqaba in the Red Sea to the Dead Sea. The plan calls for electricity generation and a large seawater desalination plan that would produce as much as 850 million cubic meters [2,788 million cubic feet] of potable water for people in the West Bank. In 2005, the governments of the three countries surrounding the Dead Sea - Israel, Jordan and the Palestinian Territories - agreed on a way to halt the sea's decline. The proposed solution entails building a $180 \mathrm{~km}$ canal and tunnel system to transfer water from the Red Sea to the Dead Sea. The three parties asked the World Bank to oversee the implementation of a feasibility study and environmental and social assessment for the project in accordance with the Bank's policies and guidelines. The feasibility study for the project is expected to take about 2 years and will cost 15.5 million USD. The study is to be financed through a multi-donor trust fund, and the project itself could cost as much as 5 billion USD and may take up to 20 years to complete [8].

The other attempt was the Qattara Depression Project [9]. The large size of the Qattara Depression and the fact that it falls to a depth of $133 \mathrm{~m}$ below mean sea level has led to several proposals to create a massive hydroelectric project in northern Egypt rivaling the Aswan High Dam. This project was known as the Qattara Depression Project. The proposals call for a large canal or tunnel being excavated from the Qattara due north of 55 to 80 kilometers to the Mediterranean Sea to bring seawater into the area. Water would flow into a series of hydro-electric penstocks which would generate electricity by releasing the water at $60 \mathrm{~m}$ below sea level. However the project has never been undertaken. Compared to the two depression sites, the Red Sea Danakil Depression hydro project would be by far the easiest to develop.

\section{A. The Red Sea Coast and Danakil Depression:}

I, along with three employees of the Eritrean Ministry of Agriculture, visited the Red Sea coastline and the Danakil land depression in the summer of 2012 (Fig. 3). The coast line on the Red Sea, from Marsa Fatima to Tio, which covers about 90 kilometers distance along the coast of Red Sea, is a flat land, without hills or ridges. Fig. 4 Sea water can be channeled inland to the Danakil Depression, with little difficulty. The topography of the land between the Red Sea coast and the depression is mostly flat without hills making it unnecessary to excavate tunnels to build a channel. Only a few kilometers of access canals from the Red Sea would be needed to access this region seawater and use it for hydroelectric project.

Traveling westward inland from the sea coast to the Danakil Depression, the elevation gradually slopes downward from the sea level to $120 \mathrm{M}$ below sea all the way to Kalul to the lowest elevation point in Eritrea. The distance between the Red Sea coast and Kalul is about 70 kilometers. The Depression covers several thousand square kilometers of flat land and stretches into Ethiopia (Fig. 5 and Fig. 6).

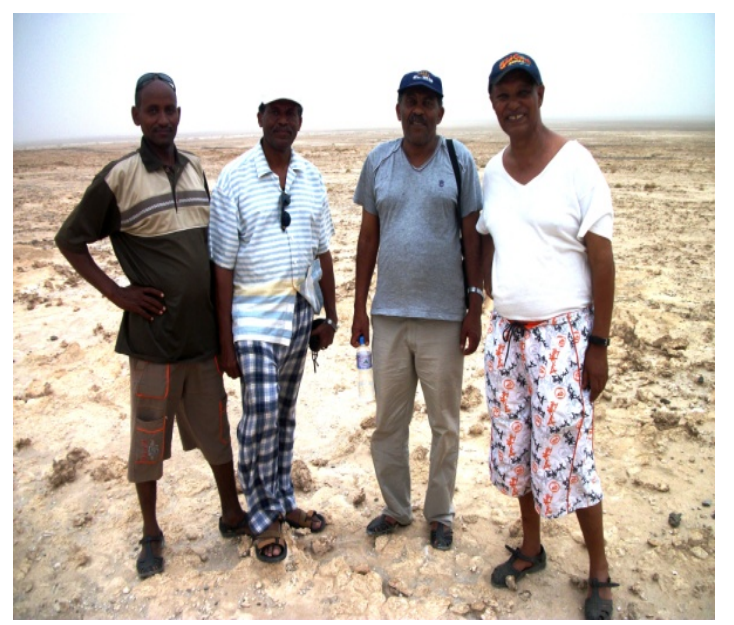

Fig. 3. Travelling Team to the Danakil Depression Summer 2012. Source H. Solomon 


\section{B. Economic Justification of Red Sea Dam}

The land at Danakil depression sinks as much as 120 meters below sea level. It is far easier to build access canals to Danakil than is the case at Qattara or the Dead Sea, because there are mountains in the way to Qattara Egypt from the Mediterranean Sea, or to the Dead Sea depression in Israel and Jordan border from the Red Sea.

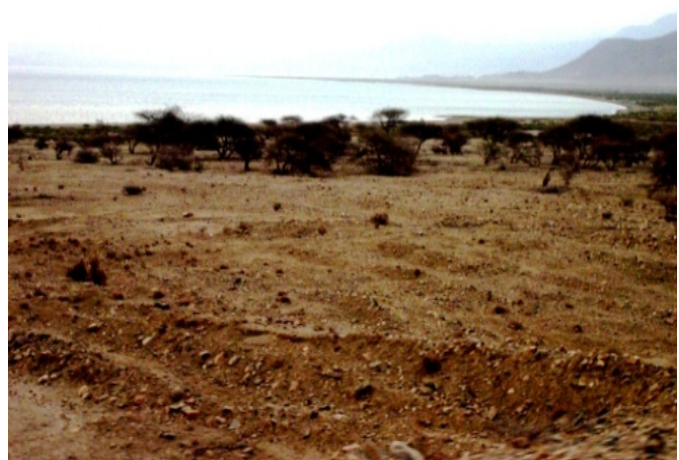

Fig. 4. Red Sea coast near Marsa Fatima and Tio, Source H. Solomon

Sea water may also be pumped using a gravity pipe to the depression, with minimum impact on the physical conditions of the area. With the availability of desalinated water the area could be transformed to green belt which can support settled agricultural activities transforming the life of the local population, for feed for domestic and wild animals in the region.

The Danakil Depression land is barren and sparsely populated. It is also the hottest area in world, temperatures reaching above 50 degree Centigrade. Because of its desert climate, it is sparsely populated and there is very little wildlife or vegetation cover thrives in the area. The few wild animals that survive the harsh climate in the Danakil Depression are few ostriches, wild donkeys and antelopes and the domestic animals are camels, donkeys and goats [Fig. $6]$.

Using the Red Sea as a natural dam has several advantages over man-made dams along a river. First there is no cost involved in building the dam. Nature has built it several billions years ago, when it created the Red Sea. Man made dams may have a limited life span, due to silt accumulation behind the dam. Man-made dams also often require a large tract of land to be flooded and submerged underwater behind the dam, creating adverse ecological problems in the short and long run. The ecological change to surrounding climate affects human settlements and wildlife and vegetation. Also artificial dams are subject to climatic changes and weather conditions such as prolonged drought and rainy seasons, causing fluctuation of the electrical generating capacities. There is no risk that the Red Sea will ever run out of water. Since the Red Sea is joined to all of the seas and oceans of the planet, the amount of seawater withdrawn will be negligible to affect the global quantity in the oceans. The evidence so far from global warming is that oceans and seas are rising. Unless there are some natural phenomena such as massive earthquakes and/or volcanic eruption that could alter the physical condition of the Red Sea and its surroundings drastically, it will remain a natural dam for Eritrea forever.

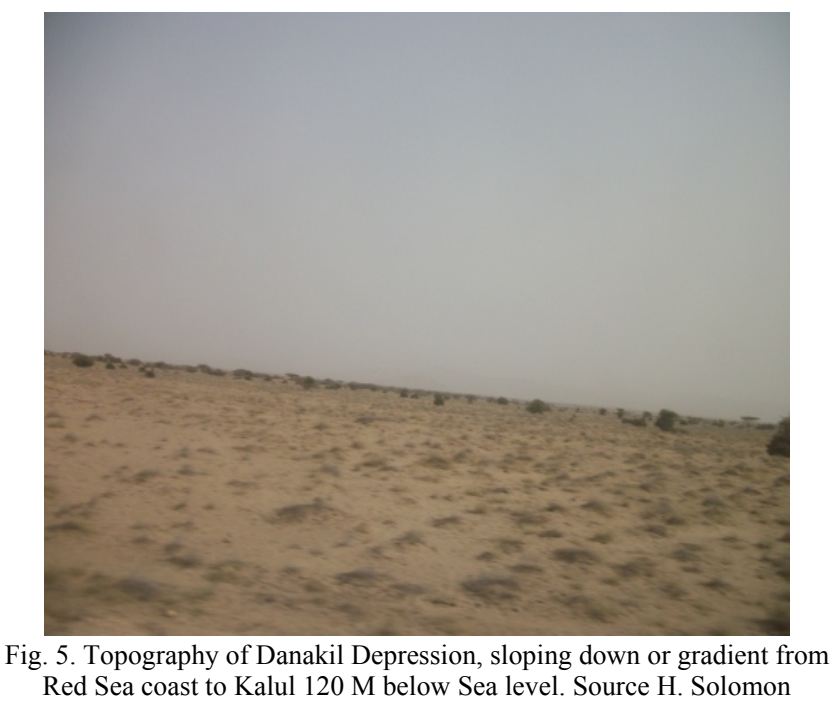

Red Sea coast to Kalul 120 M below Sea level. Source H. Solomon

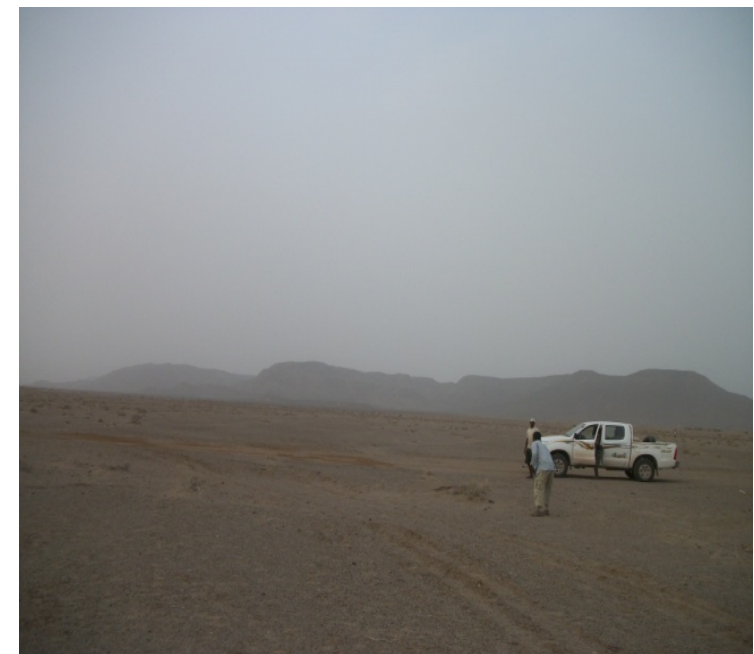

Fig. 6. the barren land of the Danakil Depression, exposed to wind erosion. Source H. Solomon

Eritrea can develop Electrical generation capacity from others energy sources wind, solar and geothermal sources. But hydro can be most efficient and the technically easy to be applied, unlike the others renewable. The cost of electrical energy from these sources can be expensive compared to hydroelectric resource. If it is feasible the project also will have other secondary benefits of generating potable water for domestic and agriculture use from desalination of reverse osmosis using the same sea water used to generate the electrical energy. The brine which is the byproduct of the desalination process can also be converted to salt, using the solar energy of high temperature and high wind velocity increase evaporation; naturally lead to make Eritrea as the lowest cost producing country of industrial salt in the world.

\section{CONCLUSION}

Eritrea can generate cheap, clean renewable and sustainable electrical energy system from the Red Sea for its immediate and foreseeable future. The Eritrean government should initiate a feasibility study of channeling seawater from the Red Sea inland to flood the Danakil Depression. International and regional development and financial organizations, concerned with global warming and poverty alleviation should be able to assist and participate in financing such study. It can be the least expensive and 
technologically simple to implement considering the proximity of Red Sea and the topography of the flat coastal landscape leading to the depression.

\section{ACKNOWLEDGEMENT}

Special Thanks to Minister Arefaine, Administrator Mr. Efrem, Public Relation officer Mr. G. Michael, Wildlife Expert Mr. Fitsum, and Driver Mr. Yosef.

\section{REFERENCES}

[1] Eritrea Country Profile, Library of Congress Federal Research, September 2005,

[2] Woldi Fitur "National Technological Capability Systems for Sustainable Economic and Social Progress: Implications for Eritrean Economy," in Emergent Eritrea G. H. Tesfagiogis Ed. Trenton NJ, The Red Sea Press, 1993, pp 263-272

[3] T. G. Gebremedhin, "Agriculture Development in Eritrea: Economic and Policy Analysis," in Emergent Eritrea G. H. Tesfagiogis Ed. Trenton NJ, The Red Sea Press, 1993, pp 99-108

[4] CIA World Fact book Eritrea Economy 2012. [Online]. Available www.theodora.com

[5] T. Araia, "The Economic Viability of an Independent Eritrea," Doctoral Dissertation, University of Nebrasa, July 1981.

[6] The World Bank Data. Electric power consumption kWh. [Online]. Available: http://data.worldbank.org/indicator/EG.USE.ELEC.KH

[7] Y. Cuddus, "Prospect of Petroleum Exploration and Production in Eritrea," in Emergent Eritrea, G. H. Tesfagiogis Ed. Trenton NJ, The Red Sea Press, 1993, pp 248-252

[8] Samiha Shafy. (September 05, 2007). The Peace Canal: Israel-Jordan Project Aims to Save Dead Sea. [Online]. Available:

http://www.spiegel.de/international/world/the-peace-canal-israel-jord an-project-aims-to-save-dead-sea-a-503953.html

[9] J. Ball, "The Qattara Depression of the Libyan Desert and the possibilities of its utilization for power production," The Geographical Journal, vol. LXXXII, no. 4, October 1933.

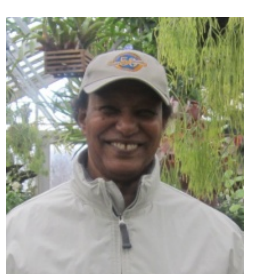

1973.

$\mathrm{He}$ is associate professor of Economics at University of the Virgin Islands, St. Thomas, US Virgin Islands. He has thought as Visiting Professor, at Alabama State University, Montgomery, Alabama and as Assistant Professor, at Tuskegee University, Tuskegee Alabama. He has also worked as Agronomist for over 10 years in Africa and the Caribbean Islands. He served as United Nations Volunteer (UNV- Agronomist) with Caribbean Regional Rural Development Advisory and Training Service (CARDATS), in St. Kitts-Nevis, St. Lucia. Before moving to West Indies he worked as Agriculture Tutor \& Farm Manager at Bishop Tucker College, Uganda and as an Agronomist and Officer-in-Charge of Makale Research Station with the Ministry of Agriculture of Ethiopia.

Dr. Solomon's research interests include Sustainable Agricultural Development and Trade Policy; Agricultural Export Promotion and Water Resource Management in the Virgin Islands. He has presented and published at local, regional and international conferences. 